\section{New Estonian records: Lichenized and lichenicolous fungi}

\section{Ave Suija ${ }^{1}$, Ede Oja ${ }^{1}$, Annika Suu ${ }^{2} \&$ Liis Marmor ${ }^{1}$}

\author{
${ }^{1}$ Department of Botany, Institute of Ecology and Earth \\ Sciences, University of Tartu, Lai St. 40, 51005 Tartu, \\ Estonia; E-mail: ede.oja@ut.ee, ave.suija@ut.ee, \\ liis.marmor@ut.ee \\ ${ }^{2}$ University of Tartu, Natural History Museum and Botanic \\ Garden, Vanemuise 46, 51014 Tartu, Estonia
}

Two species of lichenized fungi, Bacidina sulphurella and Xanthomendoza oregana, and three species of lichenicolous fungi are reported as new for Estonia. The abbreviations are used as follows: (1) for the country regions: NW - northwestern part of Estonia, SE - southeastern part, SW - southwestern part, WIs - western islands; (2) for frequency classes (Freq.): rr - very rare (1-2 localities), according to Randlane \& Saag (1999). Cited specimens are kept in the lichenological herbarium of University of Tartu Natural History Museum and Botanic Garden (TU). The lichenicolous fungi are marked with \#.

\# Arthrorhaphis olivaceae R. Sant. \& Tønsberg - SE: Tartu Co., Vara comm., Valgu $\left(58.5281888^{\circ} \mathrm{N} 26.9531^{\circ} \mathrm{E}\right)$, on Melanohalea olivacea on Picea abies. Leg. J. Liira, 16 Nov 2014, det. A. Suija, conf. A. Frisch (TU72652; ITS barcode in UNITE: UDB023348). Freq.: rr. - This rare fungus is known so far by single records from Sweden (Santesson \& Tønsberg, 1994), Belgium (Sérusiaux et al., 1999) and Greenland (Alstrup et al., 2009).

Bacidina sulphurella (Samp.) M. Hauck \& V. Wirth - SW: Viljandi Co., Kõpu comm., Soomaa National Park $\left(58.39810^{\circ} \mathrm{N} 25.199905^{\circ} \mathrm{E}\right)$, on bark of Picea abies. Leg. L. Marmor, 15 May 2014, det. E. Oja 2015, conf. A. Suija (TU75439, ITS barcode in UNITE: UDB024109); Soomaa National Park $\left(58.381545^{\circ} \mathrm{N} 25.192059^{\circ} \mathrm{E}\right)$, on wood of Pinus sylvestris. Leg. L. Marmor, 9 June 2014, det. E. Oja 2015 (TU69374). Freq.: rr - The species is probably not so rare in Estonia, but overlooked and determined as Bacidina arnoldiana. B. sulphurella is very similar to $B$. arnoldi- ana, but the conidia of $B$. sulphurella are more strongly curved and hooked while the conidia of $B$. arnoldiana are never hooked. They also differ by substrate preference: $B$. sulphurella is mostly corticolous while $B$. arnoldiana is mostly saxicolous. The comparison of the obtained rDNA ITS sequence (UDB024109) with those deposited in GenBank (http://www.ncbi.nlm.nih.gov) showed that the closest match is JN972447 (100\% of identity) defined as B. sulphurella.

\# Endococcus Ramalinarius (Linds.) D. Hawksw. - NW: Rapla Co., Kehtna comm., Kõnnumaa Landscape Reserve, Palumägi (58 $54.735^{\prime} \mathrm{N}$ $\left.25^{\circ} 01.811^{\prime} \mathrm{E}\right)$, on Ramalina farinacea on Acer platanoides at roadside, leg. A. Suija 19 June 2015, det. A. Suija (TU74949). Freq.: rr.

\# Stigmidium hafellneri Zhurb. - SW: Pärnu Co., Kihnu comm., Kihnu island, dry paludified forest $\left(58^{\circ} 08.421^{\prime} \mathrm{N} 23^{\circ} 58.204^{\prime} \mathrm{E}\right)$, on Cetraria islandica on ground, leg. A. Suija 31 May 2015, det. A. Suija (TU74950). Freq.: rr. - The rare fungus is known from tundra and taiga areas in Russia as growing on Flavocetraria cucullata (Zhurbenko, 2009) but recently has been recorded also on Cetraria islandica (M. Zhurbenko, pers. comm.). The species differs from typical Stigmidium species by having coloured (brown) ascospores.

Xanthomendoza oregana (Gyeln.) Søchting, Kärnefelt \& S.Y. Kondr. (syn. Xanthoria oregana Gyeln., Xanthoria poeltii S.Y. Kondr. \& Kärnefelt) - NW: Rapla Co., Kehtna comm., Palumägi, Kõnnumaa Landscape Reserve $\left(58.91227^{\circ} \mathrm{N}\right.$ $25.0301^{\circ} \mathrm{E}$ ), roadside, on trunk of Picea abies, leg. A. Suija 19 June 2015, det. A. Suija 30 June 2015 (TU74954); WIs: Saare Co., Saaremaa island, Lümanda comm., Viidu $\left(58^{\circ} 16.962 ' \mathrm{~N}\right.$ $22^{\circ} 07.762 ' \mathrm{E}$ ), on Acer platanoides, leg. V. Liiv 10 June 2014, det. A. Suu (TU73033; ITS barcode in UNITE: UDB022790). Freq.: rr. - The species described as Xanthoria poeltii (Kondratyuk \& Kärnefelt 1997) has been recently found to be consepecific with Xanthomendoza oregana and was synonymized accordingly (Lindblom \& Blom 2014). The taxon differs from other sorediose xanthorioid species in combination of having more adpressed thallus, blastidia on the lobe margins and only solitary rhizines, and having somewhat mottled (patchily pigmented) upper cortex related with the variable thickness 
of algal layer (Kondratyuk \& Kärnefelt, 1997). The species is known scatterly from Europe and western North America (Kondratyuk \& Kärnefelt, 1997; Lindblom \& Blom, 2014). It can be easily misidentified, especially confused with Xanthoria candelaria or Xanthomendoza fulva (Kondratyuk \& Kärnefelt, 1997), therefore $X$. oregana may be more widely distributed than known for now. The comparison of the obtained rDNA ITS sequence (UDB022790) of our specimen TU73033 with those publicly available in GenBank (http: / www.ncbi.nlm.nih.gov) showed that the first match is JQ301689 (99\% of identity) defined as $X$. poeltii ( $X$. oregana). Furthermore, we prepared an alignement using rDNA ITS sequences deposited in GenBank to confirm the sequence identity more firmly. The alignement analysis indicated that there is a high probability that the obtained sequence originates from $X$. oregana, and is clearly distinct from those of $X$. fulva and X. candelaria. - Additional specimen examined: Lichenes Danici Exsiccati 399. Xanthoria poeltii. Leg. P. Corfixen, S. N. Christensen, E. S. Hansen, 13 Oct 2004 (TU11737).

\section{ACKNOWLEDGEMENTS}

Andreas Frisch is thanked for confirmation the identity of Arthrorhaphis olivaceae, and Rasmus Puusepp for perfoming lab work. The study is financed by Estonian Research Council IUT 2030 and IUT 34-7.

\section{REFERENCES}

Alstrup, V., Kocourková, J., Kukwa, K., Motiejūnaitè, J., von Brackel, W. \& Suija, A. 2009. The lichens and lichenicolous fungi of South Greenland. Folia Cryptogamica Estonica 46: 1-24.

Kondratyuk, S. Y. \& Kärnefelt, I. 1997. Notes on the genus Xanthoria Th. Fr. Xanthoria poeltii, a new lichen species from Europe. Lichenologist 29(5): 425-430.

Lindblom, L. \& Blom, H. H. 2014. Xanthomendoza poeltii is a synonym of $X$. oregana (Teloschistaceae, lichen-forming ascomycetes). Lichenologist 46(6): 829-832.

Randlane, T. \& Saag, A. (eds) 1999. Second checklist of lichenized, lichenicolous and allied fungi of Estonia. Folia Cryptogamica Estonica 35: 1-132.

Santesson, R. \& Tønsberg, T. 1994. Arthrorhaphis aeruginosa and $A$. olivaceae, two new lichenicolous fungi. Lichenologist 26(3): 295-2299.

Sérusiaux, E., Diederich, P., Brand, A. M. \& van den Boom, P. 1999. New or interesting lichens and lichenicolous fungi from Belgium and Luxembourg. VIII. Lejeunia 162: 1-295.

Zhurbenko, M. P. 2009. Lichenicolous fungi and some lichens from the Holarctic. Opuscula Philolichenum 6: 87-2120. 